\title{
The influence of graded levels of Jerusalem artichokes and body weight on the digestibility of dietary components in a sugar cane molasses-based pig diet
}

\author{
M. Macías and J. Ly \\ Swine Research Institute \\ P.O. Box 1, Punia Brava 19200 \\ La llabana, Cuba
}

(Received 20 January 1998; accepted 24 June 1998)

\section{ABSTRACT}

Crossbred growing barrows weighing an average of $15 \mathrm{~kg}$ were divided into four groups of eight pigs in a completely randomised experiment in a $2 \times 4$ factorial design ( 20 or $55 \mathrm{~kg}$, fed $0,205,410$ or $760 \mathrm{~g} / \mathrm{kg}$ Jcrusalem artichokes). Apparent digestibility of dry matter, organic matter, energy and crude protein was progressively decreased and apparent digestibility of crude fibre and neutral detergent fibre was progressively increased by adding Jerusalem artichokes. The lower dry matter in faeces of pigs fed Jerusalem artichokes was associated with a higher faecal bulk and is suggested as being responsible for the lower digestibility of nutrients and energy in pigs fed high Jerusalem artichoke diets. Except for encrgy, pigs at $55 \mathrm{~kg}$ body weight had significantly higher or lower apparent digestibility of nutrients than pigs at $20 \mathrm{~kg}$, when Jerusalem artichokes or sugar cane molasses were the main energy source in the diet, respectively. Increasing Jerusalem artichokes increased daily faecal flow of short chain fatty acids and ammonia and reduced faecal $\mathrm{pH}$. It is concluded that there is significant adaptation to high amounts of Jerusalem artichokes in the diet with age.

KEY WORDS: pig, Jerusalem artichokes, sugar cane molasses, digestibility

\section{INTRODUCTION}

Jerusalem artichokes (Helianthus tuberosus L.) are tubers very rich in inulin, a fructan which yields fructose upon hydrolysis. Although hydrolysis of inulin does not appear to be efficient in the pig, faecal digestibility of organic matter is rather 


\section{DIGESTIBILITY OF NUTRIENTS IN PIGS FED JERUSALEM ARTICHOKES}

high (Ly et al., 1995). In contrast, Jerusalem artichokes may be responsible for a depression in $\mathrm{N}$ digestibility of the diet (Ly et al., 1995).

Sugar cane molasses is a common feed in several tropical countries (Gohl, 1975). In Cuba, sugar cane molasses type B is utilised in pig feeding practice. This type of molasses originates from the second of three sugar extractions in a sugar factory. The nutritive value of sugar cane molasses type B is well established (Ly, 1996).

On the other hand, the ability of the pig to digest several components of conventional diets may increase with age (Everts et al., 1986; Fernández et al., 1986; Shi and Noblet, 1993) or not (Kass et al., 1980; Everts et al., 1986). Therefore it could be of interest to determine if digestibility of dicts based on Jerusalem artichokes and sugar cane molasses could be improved with age or body weight.

The present experiment was designed to determine the effect of graded levels of Jerusalem artichokes in the diet and body weight on the digestibility of dietary components in a sugar canc molasses-based dict. In addition some fermentative indices from faeces of pigs were estimated.

\section{MATERIAL AND METHODS}

Crossbred growing barrows (Yorkshirc $\mathrm{x}$ Landrace $\mathrm{x}$ Duroc) weighing on average $15 \mathrm{~kg}$ were from an earlier feeding trial (Macías, 1994; unpublished data). The animals were divided into four groups of eight to a completely randomised experiment in a $2 \times 4$ factorial design and fed ad libitum the diets presented in Table 1 . The energy sources of the dicts were sugar cane molasses type B $(751.5 \mathrm{~g} / \mathrm{kg}$ DM) and Jerusalem artichoke tubers (244.1 g/ kg DM). The Jerusalem artichokes were harvested in Cuba and frozen immediately until utilisation (Modler et al., 1993). Graded levels of Jerusalem artichokes were incorporated into diets at the expense of the sugar canc molasses but adjusting the soyabean meal proportion in the dietary formula in order to maintain the constant protein level $(160 \mathrm{~g} / \mathrm{kg}$ in dry basis). Sugar cane molasses was mixed with soyabcan meal, mincrals and vitamins and then given to the animals. Thereafter the tubers were offered to the pigs in order to assure the complete consumption of the other components of the ration. The animals were fed once a day at $9.00 \mathrm{~h}$.

Pigs were individually kept in $0.5 \times 1.25 \mathrm{~m}$ concrete-floor pens in an open shed-type house. The pens were equipped with individual feeding stalls and nipple-waterers.

Facces were collected from individual pigs at $8.00 \mathrm{~h}$ by grab sampling from each animal at 20 and $55 \mathrm{~kg}$ on average. The $\mathrm{pH}$ value was measured potentiometrically in fresh faeces. The SCFA and ammonia were determined in fresh faeces as described by Ly et al. (1995). Faeces from cach pig were dried in a forced-air oven at $65^{\circ} \mathrm{C}$ for $48 \mathrm{~h}$. The oven-dried faeces were allowed to come to equilibrium with 
TABL.E. 1

Composition of the diets

\begin{tabular}{|c|c|c|c|c|}
\hline & \multicolumn{4}{|c|}{ Jerusalem artichokes, $\mathrm{g} / \mathrm{kg}$} \\
\hline & 0 & 205 & 410 & 760 \\
\hline \multicolumn{5}{|l|}{ Ingredients, $\mathrm{g} / \mathrm{kg}$} \\
\hline soyabcan meal & 332.6 & 295.4 & 257.7 & 194.0 \\
\hline sugar cane molasses type B & 621.4 & 453.6 & 256.3 & - \\
\hline Jerusalem artichoke tubers & - & 205.0 & 410.0 & 760.0 \\
\hline $\mathrm{CaHPO} \cdot 2 \mathrm{H}_{2} \mathrm{O}$ & 30.0 & 30.0 & 30.0 & 30.0 \\
\hline $\mathrm{NaCl}$ & 6.0 & 6.0 & 6.0 & 6.0 \\
\hline vitamins and trace elements ${ }^{1}$ & 10.0 & 10.0 & 10.0 & 10.0 \\
\hline \multicolumn{5}{|l|}{ Chemical composition, $\mathrm{g} / \mathrm{kg}$} \\
\hline $\begin{array}{l}\text { dry matter } \\
\text { in dry matter }\end{array}$ & 801.0 & 548.4 & 416.7 & 295.6 \\
\hline ash & 108.6 & 104.7 & 99.5 & 93.7 \\
\hline organic matter & 891.4 & 895.3 & 900.5 & 906.3 \\
\hline crude protein & 160.0 & 160.0 & 159.0 & 159.0 \\
\hline crude fibre & 27.8 & 41.7 & 54.7 & 72.0 \\
\hline NDF & 43.6 & 64.3 & 85.1 & 95.0 \\
\hline energy, KJ/10 g DM & 146.8 & 152.4 & 158.0 & 167.5 \\
\hline
\end{tabular}

1 supplied per kg of diet: 1600 I.U. A, 160 I.U. D, $2 \mathrm{mg}$ thiamine, $3 \mathrm{mg}$ riboflavine, $300 \mathrm{mg}$ choline, $15 \mathrm{mg}$ niacin, $5 \mathrm{mg}$ panthotenic acid, $15 \mathrm{mg}$ pyridoxine, $0.5 \mathrm{mg}$ folic acid, $25 \mu \mathrm{g}$ cyanocobalamin, $10 \mathrm{mg}$ tocopheryl acetate, $2 \mathrm{mg}$ vitanin $\mathrm{K}, 10 \mathrm{mg} \mathrm{Cu}, 40 \mathrm{mg} \mathrm{Fc}, 0.5 \mathrm{mg} \mathrm{I}, 0.4 \mathrm{mg}$ Co acetate, $2 \mathrm{mg}$ vitamin $\mathrm{K}, 10 \mathrm{mg} \mathrm{Cu}, 40 \mathrm{mg} \mathrm{Fe}, 0.5 \mathrm{mg} \mathrm{l}, 0.4 \mathrm{mg} \mathrm{Co}$

the air moisture and ground in a Willey type mill to pass through a $1 \mathrm{~mm}$ screen. Dry matter (DM), crude protein, crude fibre and ash were determined by $\Lambda \mathrm{O} \Lambda \mathrm{C}$ methods (1984). Neutral detergent fibre (NDF) was estimated according to the procedure of Van Soest and Wine (1967). The gross energy of the feed and faeces werc determined with an adiabatic bomb calorimeter. Acid insoluble ash was used as an indicator for determining apparent digestibility coefficients. Concentrations of acid insoluble ash in feed and faeces were estimated by the method of Van Kculen and Young (1977).

The estimates of daily faeces output were calculated using the equation:

fresh faeces flow $(\mathrm{g})=$ feed intake $(\mathrm{g}$ DM)

$$
\mathrm{x} \frac{100-\text { apparent DM digestibility }(\mathrm{g} / \mathrm{kg})}{100} \times \frac{100}{\text { faceal DM }(\%)}
$$

Least square analysis was used to examine the data collected on the pigs (Harvey, 1987), and the following model was used:

$$
\mathrm{Y}_{\mathrm{ijk}}=\mu+\mathrm{a}_{\mathrm{i}}+\mathrm{b}_{\mathrm{i}}+\mathrm{a} \mathrm{b}_{\mathrm{ij}}+\mathrm{e}_{\mathrm{ijk}}
$$


where: $\mathrm{Y}_{\mathrm{ijk}}$ is the digestion index in the $\mathrm{k}^{\mathrm{th}}$ pig on the ai diet on the $\mathrm{b}_{\mathrm{j}}$ body weight; $\mu$ is the overall mean; $a_{i}$ is the effect of the $i^{\text {th }}$ diet; $b_{j}$ is the cffect of the $j^{\text {th }}$ body weight; $a b_{i j}$ is the interaction term and $e_{i j k}$ is the random error.

The Duncan multiple range test was used to compare the means when the F test was significant. Some data were subjected to regression analyses, with linear components measuring the relationships between organic matter (OM) digestibility and other digestion parameters, as outlined by Steel and Torrie (1980).

\section{RESULTS}

Voluntary intake of the diet accounted for $0.131 \pm 0.011 \mathrm{~kg} \mathrm{DM} / \mathrm{W}^{0.75}$ per day and no differences due to the nature of the diet were noted.

The nutrient digestibilities of the diets are shown in Table 2, and the statistical analysis in Table 3. Apparent digestibility of DM and energy appeared to increase and apparent digestibility of NDF to decrease with decreasing the level of Jerusalem artichokes in the diet, and feeding zero $g$ of these tubers per $\mathrm{kg}$ of diet appeared to result in greater DM, energy and NDF digestibility at $20 \mathrm{~kg}$ of body weight than at $55 \mathrm{~kg}$. In fact energy was best digested in all diets at $20 \mathrm{~kg}$. The dict effect was more evident in energy and NDF $(\mathrm{P}<0.001)$ than in DM digestibility

TABLE 2

Nutrients and energy apparent digestibility

\begin{tabular}{lccccc}
\hline \multirow{2}{*}{$\begin{array}{l}\text { Fecal digestibility, } \\
\mathrm{g} / \mathrm{kg}\end{array}$} & $\begin{array}{c}\text { Body } \\
\text { weight, } \mathrm{kg}\end{array}$ & 0 & 205 & 410 & 760 \\
\cline { 3 - 6 } Dry matter & 20 & 940 & 913 & 846 & 812 \\
& 55 & 899 & 873 & 855 & 841 \\
Ash & 20 & $861^{\mathrm{a}}$ & $818^{\mathrm{ab}}$ & $664^{\mathrm{c}}$ & $493^{\mathrm{d}}$ \\
& 55 & $751^{\mathrm{ab}}$ & $726^{\mathrm{b}}$ & $722^{\mathrm{b}}$ & $695^{\mathrm{b}}$ \\
Organic matter & 20 & $950^{\mathrm{a}}$ & $925^{\mathrm{ab}}$ & $866^{\mathrm{cd}}$ & $844^{\mathrm{d}}$ \\
& 55 & $914^{\mathrm{b}}$ & $882^{\mathrm{c}}$ & $871^{\text {cd }}$ & $861^{\mathrm{dd}}$ \\
Crude protein & 20 & $886^{\mathrm{a}}$ & $825^{\mathrm{a}}$ & $698^{\mathrm{c}}$ & $594^{\mathrm{d}}$ \\
& 55 & $732^{\mathrm{b}}$ & $691^{\mathrm{c}}$ & $714^{\mathrm{c}}$ & $689^{\mathrm{c}}$ \\
Crude fibre & 20 & $522^{\mathrm{c}}$ & $566^{\mathrm{c}}$ & $635^{\mathrm{b}}$ & $635^{\mathrm{b}}$ \\
& 55 & $337^{\mathrm{d}}$ & $491^{\mathrm{c}}$ & $531^{\mathrm{c}}$ & $838^{\mathrm{a}}$ \\
NDF & 20 & 535 & 586 & 593 & 637 \\
& 55 & 532 & 660 & 670 & 754 \\
Encrgy & 20 & 943 & 918 & 860 & 847 \\
& 55 & 897 & 858 & 856 & 828 \\
\hline
\end{tabular}

$a, b, c, d-$ means within comparison groups bearing the same letter are not significantly different at $\mathrm{P}<0.05$ 
TABLE 3

Analysis of variance for faccal digestibility

\begin{tabular}{lcccc}
\hline & \multicolumn{4}{c}{ Source of variation } \\
\cline { 2 - 5 } & diet & $\begin{array}{c}\text { body } \\
\text { weight, } \mathrm{kg}\end{array}$ & $\mathrm{D} \times \mathrm{W}$ & error \\
\hline $\begin{array}{l}\text { Degree of lreedom } \\
\text { Mean square }\end{array}$ & 3 & 1 & 3 & 56 \\
faccal digestibility & & & & \\
$\quad$ dry matter & $28023^{*}$ & 1903 & 5181 & 9571 \\
ash & $142268^{* * *}$ & 3306 & $85089^{* * *}$ & 4099 \\
organic matter & $20332^{* * *}$ & $3039^{* *}$ & $3426^{* *}$ & 683 \\
crude protein & $82151^{* * *}$ & $6687^{* *}$ & $64341^{* * *}$ & 4725 \\
crude fibrc & $250241^{* * *}$ & 11285 & $118284^{* *}$ & 22907 \\
NDF & $57965^{* * *}$ & $87173^{* * *}$ & 5326 & 4221 \\
energy & $20644^{* * *}$ & $166641^{* * *}$ & 2540 & 914 \\
\hline
\end{tabular}

${ }^{*} \mathrm{P}<0.05 ;{ }^{* *} \mathrm{P}, 0.01 ; * * \mathrm{P}<0.001$

$(\mathrm{P}<0.05)$. The apparent differences in the body weight effect were significant $(\mathrm{P}<0.001)$ in energy and NDF digestibility. In fact digestibility of NDF appeared to improve as pigs aged from 20 to $55 \mathrm{~kg}$ ( 588 and $662 \mathrm{~g} / \mathrm{kg}$, respectively), whilst digestibility of energy was impaired ( 982 and $858 \mathrm{KJ} / \mathrm{MJ}$, respectively). In this connection, the apparent digestibilitics of both DM and encrgy decreased with the increase of body weight in the case where sugar cane molasses was predominant in the diet. The interaction between diet and body weight of the pigs was not statistically significant for these parameters.

The effect of diet was highly significant $(\mathrm{P}<0.001)$ for apparent digestibility of ash, organic matter $(\mathrm{OM})$, crude protein and crude fibre. In fact, ash, OM and crude protein digestibility decreased as long as crude fibre digestibility increased with the inclusion of graded levels of Jerusalem artichokes in the diet. On the other hand the effect of body weight was significant $(\mathrm{P}<0.01)$ for crude protein and $\mathrm{OM}$ digestibility. Both crude protein and OM digestibilities decreased from 751 and $896 \mathrm{~g} / \mathrm{kg}$ at $20 \mathrm{~kg}$ to 707 and $882 \mathrm{~g} / \mathrm{kg}$ at $55 \mathrm{~kg}$, respectively. The interaction diet $\mathrm{x}$ body weight was significant $(0.0 \mathrm{l}<\mathrm{P}<0.001)$ for $\mathrm{ash}, \mathrm{OM}$, crude protein and crude fibre digestion coefficients.

Faccal apparent energy digestibility $(\mathrm{Y}, \%)$ correlated $(\mathrm{r}-0.916, \mathrm{P}<0.001)$ with faecal apparent $\mathrm{OM}$ digestibility $(\mathrm{X}, \%)$ according to the regression equation:

$$
\mathrm{Y}=1.011 \mathrm{X}( \pm 0.056)-2.294
$$

Faecal data of pigs fed Jerusalem artichokes and sugar cane molasses at different body weights are listed in Table 4, whilst the statistical analysis is presented in Table 5. Increasing the Jerusalem artichoke levels in the diet significantly decreased faecal DM and $\mathrm{pH}$ and increased SCFA concentration $(\mathrm{P}<0.001)$. Faecal ammonia 
TABLE 4

Faecal indices and daily faeces output

\begin{tabular}{|c|c|c|c|c|c|}
\hline & \multirow{2}{*}{$\begin{array}{c}\text { Body } \\
\text { weight, kg }\end{array}$} & \multicolumn{4}{|c|}{ Jerusalem artichokes, $\mathrm{g} / \mathrm{kg}$} \\
\hline & & 0 & 205 & 410 & 760 \\
\hline \multicolumn{6}{|l|}{ Faecal indices } \\
\hline \multirow[t]{2}{*}{$\mathrm{DM}, \mathrm{g} / 100 \mathrm{~g}$} & 20 & 22.49 & 18.55 & 16.88 & 13.56 \\
\hline & 55 & 21.28 & 20.67 & 18.55 & 17.51 \\
\hline \multirow[t]{2}{*}{$\mathrm{pH}$} & 20 & 6.90 & 6.43 & 6.18 & 6.00 \\
\hline & 55 & 7.20 & 6.96 & 6.38 & 5.90 \\
\hline \multicolumn{2}{|c|}{$\mathrm{SCFA}, \mathrm{mmol} / 100 \mathrm{~g} \mathrm{DM} 20$} & $19.2^{\mathrm{a}}$ & $61.3^{\mathrm{b}}$ & $54.3^{\mathrm{ab}}$ & $110.6^{\mathrm{c}}$ \\
\hline & 55 & $35.2^{\mathrm{ab}}$ & $41.2^{\mathrm{ab}}$ & $45.7^{\text {ab }}$ & $48.3^{\text {ih }}$ \\
\hline \multirow[t]{2}{*}{$\mathrm{NH}_{3}, \mathrm{mmol} / 100 \mathrm{~g} \mathrm{DM}$} & 120 & 19.3 & 28.2 & 22.0 & 28.0 \\
\hline & 55 & 43.1 & 39.4 & 35.9 & 29.0 \\
\hline \multicolumn{6}{|c|}{ Daily faecal output $/ \mathrm{kg}$ DM intakc } \\
\hline \multirow{2}{*}{ fresh facces, $g$} & 20 & $289^{\mathrm{a}}$ & $469^{\text {atb }}$ & $865^{\mathrm{c}}$ & $1386^{d}$ \\
\hline & 55 & $531^{\text {at }}$ & $619^{\mathrm{b}}$ & $852^{\mathrm{c}}$ & $908^{\mathrm{r}}$ \\
\hline \multirow{2}{*}{ water, $\mathrm{g}$} & 20 & $224^{a}$ & $382^{\mathrm{b}}$ & $719^{4}$ & $1198^{\mathrm{c}}$ \\
\hline & 55 & $418^{\mathrm{b}}$ & $491^{\text {bc }}$ & $694^{\mathrm{cd}}$ & $749^{d}$ \\
\hline \multirow[t]{2}{*}{ SCFA, mmol } & 20 & $11.3^{\mathrm{a}}$ & $47.3^{\mathrm{a}}$ & $81.6^{\mathrm{b}}$ & $209.3^{c}$ \\
\hline & 55 & $32.6^{\mathrm{a}}$ & $51.6^{\mathrm{a}}$ & $69.0^{\mathrm{ab}}$ & $75.0^{\mathrm{b}}$ \\
\hline \multirow[t]{2}{*}{$\mathrm{NH}_{3}, \mathrm{mmol}$} & 20 & 11.4 & 24.3 & 30.1 & 53.3 \\
\hline & 55 & 41.6 & 50.8 & 51.1 & 53.3 \\
\hline
\end{tabular}

$a, b, c, d, e-$ means within comparison groups bearing the same letter are not significantly different $(\mathbf{P}<0.05)$

TABLE 5

Analysis of variance for faecal indices

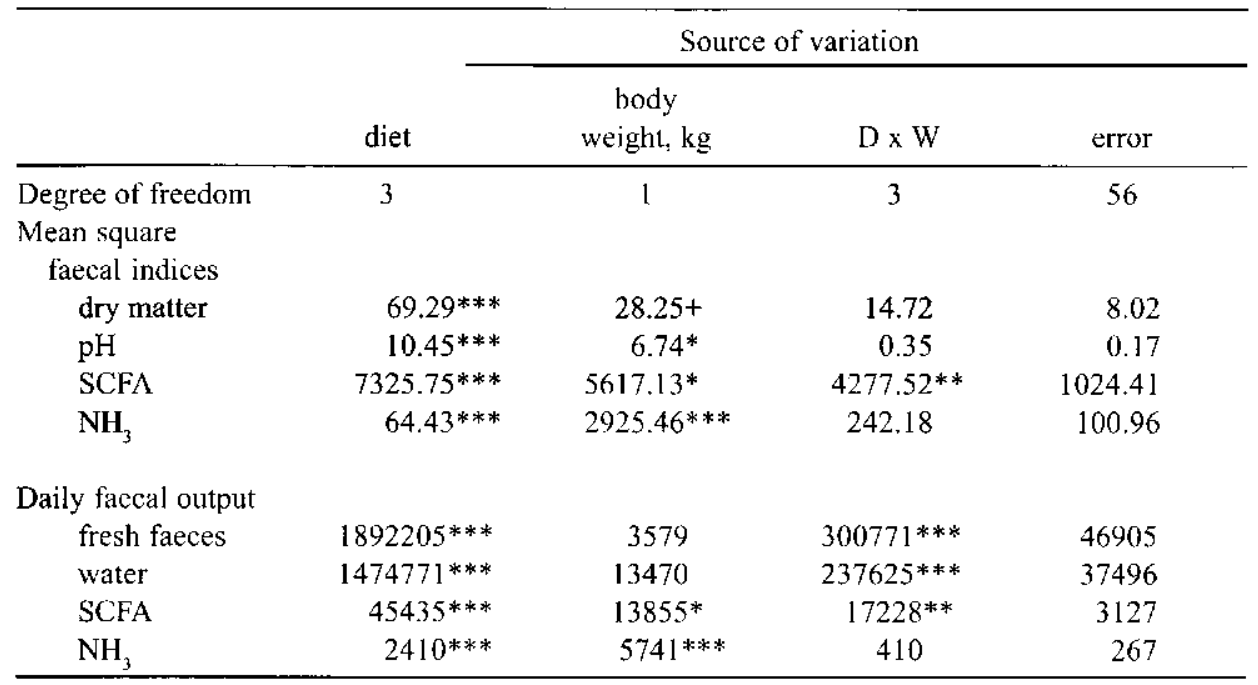

$+\mathrm{P}<0.10 ;{ }^{*} \mathrm{P}<0.05 ;{ }^{* *} \mathrm{P}<0.01 ;{ }^{* * *} \mathrm{P}<0.001$ 
concentration was not affected by diet. On the other hand, body weight markedly influenced the faecal concentration of these metabolites $(\mathrm{P}<0.001)$; this cffect was least significant for faecal $\mathrm{pH}$ and SCFA concentration $(\mathrm{P}<0.05)$. In fact, faecal $\mathrm{pH}$ and ammonia concentration increased from 6.38 and $24.4 \mathrm{mmol} / 100 \mathrm{~g} \mathrm{DM}$ at 20 $\mathrm{kg}$ to 6.61 and $36.8 \mathrm{mmol} / 100 \mathrm{~g} \mathrm{DM}$ at $55 \mathrm{~kg}$. The reverse was evident for SCFA concentration in faeces (from 61.4 to $42.6 \mathrm{mmol} / 100 \mathrm{~g}$ DM respectively). The interaction diet $\mathrm{x}$ body weight was only significant $(\mathrm{P}<0.001)$ for faecal SCFA concentration.

The effect of diet showed a highly significant influence $(\mathrm{P}<0.001)$ on either fresh faecal and water flow, or SCFA and ammonia. The general trend was toward an increased daily faecal flow in direct association with increased levels of Jerusalem artichokes in the diet. The effect of body weight was significant for daily faecal flow of ammonia ( $\mathrm{P}<0.001)$ or SCFA $(\mathrm{P}<0.05)$, respectively, which either increased from 29.8 to 49.2 or was depressed from 87.4 to $57.1 \mathrm{mmol} / \mathrm{day}$ per $\mathrm{kg}$ DM intake, respectively. A significant diet $\mathrm{x}$ body weight interaction was found for daily faecal fresh material and water $(\mathrm{P}<0.001)$ and SCFA $(\mathrm{P}<0.01)$ flows, respectively.

A significant correlation $(\mathrm{r}=-0.772 ; \mathrm{P}<0.05)$ existed for organic matter digestibility $(\mathrm{x}, \%)$ and daily faecal flow of SCFA (Y, mmol/kg DM intake per day), with the regression equation:

$$
\mathrm{Y}=1200.27-12.69 \mathrm{x} \pm 4.26
$$

\section{DISCUSSION}

The animals fed on either sugar cane molasses or Jerusalem artichokes did not develop diarrhoea defined as profuse unformed faeces, despite the low faecal dry matter concentration observed throughout the experiment. However, the introduction of Jerusalem artichokes into a sugar cane molasses diet led to a considerable increase in faecal bulk, in agreement with previous observations by Ly et al. (1995). In this connection, microbial digestion of fructans rather than that of cell wall or non-starch polysaccharides contained in Jerusalem artichokes could be responsible for this phenomenon. This hypothesis arises from results of Graham and Åman (1986) who found that precaecal and faecal DM digestibility in Jerusalem artichokes was 40 and $90 \%$, respectively. Comparable values have been obtained for artichoke tubers (Ly et al., 1995). Therefore, fructans from Jerusalem artichokes degraded in the large intestine may largely increase faecal bulk and produce softer faeces, similarly as is the case with soluble dietary fibre in humans (Stephen and Cumming, 1980), rats (Nyman and Asp, 1982) and pigs (Graham and Åman, 1987; Bach Knudsen and Hansen, 1991). 
In this study the increase in faecal bulk was evident when pigs were fed diets with increasing proportions of Jerusalem artichokes. Furthermore, an inverse relationship appeared to exist between high levels of dietary Jerusalem artichokes and nutrients and energy digestibility. In this connection the excretion of soft faeces with a relatively low dry matter content by pigs has been related to reduced retention time of feed residues in the digestive tract (Cherbut and Ruckebusch, 1985; Metz and Dekker, 1985). On the other hand, a low retention time of undigested matter has been shown to be directly responsible for lowering the digestibility of several dietary components under variable circumstances in the pig (Kass et al., 1980; Metz and Dekker, 1985; Mroz ct al., 1986). Therefore it can be assumed that this was the case in the present experiment.

The decrease in apparent digestibility of nutrients with increasing Jerusalem artichokes in the diet, except for the crude fibre and NDF fractions, is in agreement with previous observations related to growing pigs (Ly et al., 1995). Nevertheless, a slight increase in nutrient digestibility with increasing body weight of pigs fed Jerusalem artichokes as the only energy source in the diet is in accordance with experimental data indicating a positive influence of age or body weight on digestibility of nutrients from conventional diets in the growing pig (Fernández et al., 1984; Everts et al., 1986; Shi and Noblet, 1993). However a reduction in nutrient digestibility with increasing body weight of pigs fed sugar cane molasses was unexpected, taking into account the data of Jentsch et al. (1991). It appears that additional research is needed to identify mechanisms by which body weight or age influence nutrient digestion by pigs fed sugar cane molasses.

A substantial change in concentration and daily flow of end-products of microbial metabolism, along with a modification in faecal $\mathrm{pH}$ in pigs fed either sugar cane molasses or Jerusalem artichokes was found in the present study. Moreover, the effect of body weight on faecal SCFA, ammonia and $\mathrm{pH}$ was also cvident, thus implying a long-term adaptation of the animals to the type of diet fed. The nature of the dietary source of carbohydrates was obviously responsible for such changes. In this connection, Bach Knudsen et al. (1991) showed that caccal and colonic $\mathrm{pH}$ decreased as a consequence of fermentation of the carbohydrates and amount of feed residues reaching the large intestine. Furthermore Ehle et al. (1982) and Varel et al. (1984) found differences in faccal concentration of SCFA in pigs fed high and low fibre dicts. The same differences were observed in caecal and colonic digesta by Varel et al. (1984). Nevertheless, attempts to achieve changes in faecal SCFA caused by Jerusalem artichokes in very young pigs have not been consistent (Farnworth, 1994; Farnworth et al., 1995), probably due to the low level of fructans included in the diet.

High faecal ammonia excretion caused by Jcrusalem artichokes has previously been observed by Ly ct al. (1995). In this connection Bolduan et al. (1986) have suggested that a straight relation between SCFA and ammonia concentrations does 
exist in the colonic digesta and facces of pigs, whilst Varel et al. (1984) observed high faecal ammonia concentrations in pigs fed diets high in fibre. The correlation was more apparent in the present study for daily faccal flow of both types of metabolites, perhaps as a function of retention time of digesta in the large intestine of the animals.

In conclusion, a decrease in digestibility of nutrients from diets containing Jerusalem artichokes depends on the level at which the tubers are introduced into the diet. On the other hand, significant adaptation to high amounts of Jerusalem artichokes with age of pigs may also be expected.

\section{REFERENCES}

AOAC, 1984. Official Methods of Analysis. 14th Edition. Association of Official Analytical Chemists. Washington, DC

Bach Knudsen K.E., Hansen I., 1991. Gastrointestinal implications in pigs of wheat and oat fractions. 1. Digestibility and bulking properties of polysaccharides and other major constituents. Brit. J. Nutr. 65, 217-232

Bach Knudsen K.E., Jensen H.B., Andersen J.D., Hansen I., 1991. Gastrointestinal implications in pigs of wheat and oat fractions. 2. Microbial activity in the gastrointestinal tract. Brit. J. Nutr. $65,233-248$

Bolduan G., Schneider R., Jung H., Klenke H., 1986. The ammonia content in the digesta of pigs. Arch. Anim. Nutr. (Berlin) 36, 281-285

Cherbut Ch., Ruckebusch Y., 1985. The effect of indigestible particles on digestive transit time and colonic motility in dogs and pigs. Brit. J. Nutr. 53, 549-557

Ehle F.R., Jcraci J.L., Robertson J.B., Van Soest P.J., 1982. The influence of dietary fiber on digestibility, rate of passage and gastrointestinal fermentation in pigs. J. Anim. Sci. 55, 1071-1081

Everts H., Smits B., Jongbloed A.W., 1986. Effect of crude fibrc, fecding level and body weight on apparent digestibility of compound feeds by swine. Netherlands J. $\Lambda$ gric. Sci. 34, 501-503

Farnworth E.R., 1994. Feeding Jerusalen artichoke (Ielianthus abberosus) to pigs. J. Sci. Food Agric. 64, 217-221

Farnworth E.R., Modler H.W., Mackie D.A., 1995. Adding Jerusalem artichoke (Helianthus tuberosus L.) to weanling pig diets and the effect on manure composition and charactcristics. Anim. Feed Sci. Technol. 55, 153-160

Femández J.A., Jorgensen H., Just A., 1986. Comparative digestibility experiments with growing pigs and adult sows. Anim. Prod. 43, 127-132

Gohl B., 1975. Tropical Feeds. In: Feeds Information Summaries and Nutritive Value, FAO Rome

Graham H., Åman P., 1986. Composition and digestion in the pig gastrointestinal tract of Jerusalem artichoke tubers. Food Chem. 22, 67-76

Graham H., Åman P., 1987. The pig as a model in dietary fibre digestion studies. Scand. J. Gastroent. 22, Suppl. 129, 55-61

Harvey W.R., 1987. User's Guide for LSMLMW Mixed Model Least Squares and Maximum Likelihood Computer Program (Mimeo). Ohio State University, Wooster

Jentsch W., Kesting U., Block H.J., 1991. Zur scheinbaren prazakalen Nährstoffverdaulichkeit und Energieverweltung von Melasse beim Schwein. 1. Energieumsatz. Arch. Anim. Nutr. (Berlin) $41,717-724$ 


\section{DIGESTIBILITY OF NUTRIENTS IN PIGS FED JERUSALEM ARTICHOKES}

Kass M.L., Van Soest P.J., P’ond W.G., Lewis B., McDowell R.F., 1980. Utilization of dietary fiber from alfalfa by growing swine. I. Apparent digestibility of diel components in specific segments of the gastrointestinal tract. J. Anim. Sci. 50, 175-191

Ly J., 1996. The pattern of digestion and metabolism in high sugar feeds for pigs. Cuban J. Agric. Sci. 30, 117-129

Ly J., Macias M., Reyes J.I.., Figueroa V., 1995. Ileal and faecal digestibility of Jcrusalem artichokes (Ilelianthus tuberosus L.) in pigs. J. Anim. Fecd Sci. 4, 195-205

Metz S.H.M., Dekker R.A., 1985. Effects of housing on gastrointestinal transit time and digestibility of feeds in growing pigs, In: A. Just, H. Jorgensen, J.A. Fernández (Editors). Digestive physiology in the pig. Heret. Statens Husdyrbrugsforsog. Copenhagen, pp. 369-372

Modler H.W., Jones J.D., Ma7za G., 1993. Some aspects of storage and processing of Jerusalcm artichoke tubers (Ilelianthus tuberosus). Food Chem. 48, 279-284

Mroz Z. , Partidge I .G., Mitchcll G., Keal H.D., 1986. The effect of oat hulls, added to the basal ration for pregnant sows, on reproductive performance, apparent digestibility, rate of passage and plasma parameters. J. Sci. Food Agric. 37, 239-247

Nyman M., Asp N.G., 1982. Fermentation of dietary fibre components in the rat intestinal tract. Brit. J. Nutr. 47, 357-366

Shi X.S., Noblet J., 1993. Contribution of the hindgut to digestion of diets in growing pigs and adult sows: effect of diet composition. Livest. Prod. Sci. 34, 237-252

Steel R.G.D., Torrie J.H., 1980. Principles and Procedures of Statistics. A Biometrical Approach. 2nd Fdition. McGraw-Hill Book Co. Inc., Toronto, pp. 633

Stephen A.M., Cumming J.H., 1980. The microbial contribution to human faccal mass. J. Med. Microbiol. 13, 45-5b

Van Keulen J., Young S.A., 1977. Evaluation of acid insoluble ash as a natural marker in ruminant digestibility studies. J. Anim. Sci. 44, 262-266

Van Soest P.J., Wine R.H., 1967. Use of detergents in the analysis of fibrous feed. 4. Determination of plant ccll-wall constitucnts. J. Assoc. Off. Anal. Chem. 50, 50-55

Varel V.H., Pond W.G., Yen I.T., 1984. Influence of dietary fiber on the performance and cellulase activity of growing-finishing swine. J. Anim. Sci. 59, 388-393

\section{STRESZCZENIE}

\section{Wpływ udzialu topinamburu i masy ciała świń na strawność składników pokarmowych dawek z dużym udziałem melasy $\mathrm{z}$ trzciny cukrowej}

Mieszańcc - wieprzki o średnicj masic ciała $15 \mathrm{~kg}$, podzielono na 4 grupy po 8 , w doświadczeniu o układzie czynnikowym $2 \times 4$ (20 lub $55 \mathrm{~kg}$, udział topinamburu w dawce 0, 205, 410 lub 760/ kg). Pozorna strawność suchej masy, substancji organicznej, energii i białka ogólnego obniżała sic̨ stopniowo, a strawność włókna i NDF zwiększała się w miarç zwiçkszania udziału topinambunı w dawce. Mnicjsza zawartość suchej masy w kale i związana z tym większa ilość kału u świń otrzymujących topinambur mogły być wynikiem gorszej strawności składników pokarmowych i energii dawek zawierających dużą ilość topinamburu. Z wyjątkiem energii, pozorna strawność składników pokarmowych dawek była istotnie większa u świń 55 nì $20 \mathrm{~kg}$, gdy glówne źródło energii w dawkach stanowił topinambur, a mniejs za gdy źródłem energii była melasa z trzciny cukrowej. Zwiększenie ilości skarmianego topinamburu zwiększało dzienne wydalanic krótkołańcuchowych kwasów thuszczowych i amoniaku w kale oraz obniżało pH kału. Stwierdzono, że wraz z wiekiem zwierzęta przystosowują się do dużych ilości topinamburu w diecie. 